\title{
Forbedring krever gode data
}

\author{
For å forbedre må man kunne måle. Prevalensdata for sykehusinfeksjoner er upresise og beheftet med \\ stor usikkerhet. Helse Sør-Øst bør satse på insidenstall for postoperative sårinfeksjoner, som er de infek- \\ sjoner som bidrar mest til mortalitet, morbiditet og kostnader. Slike data er tilgjengelige gjennom Norsk \\ overvåkingssystem for infeksjoner i sykehustjenesten (NOIS).
}

Manglende måloppnåelse bør utløse forbedringsarbeid. Men for å forbedre må man kunne måle. Slike enkle krav må oppfylles av alle som etablerer mål for forbedring. Det er oppløftende at Helse Sør-Øst fra og med 2011 inkluderer sykehusinfeksjoner i ett av fem hovedmål. Det er trist at datagrunnlaget som er valgt, er uegnet for forbedring. Prevalensdata for sykehusinfeksjoner er nemlig upresise og beheftet med

grepet, mens prevalenstall kun omfatter inneliggende pasienter. Det er også verdt å merke seg at den vesentlige delen av infeksjoner som følge av kirurgi oppstår etter utskrivning. Den nasjonale pasientsikkerhetskampanjen I trygge hender er rettet blant annet mot slike sykehusinfeksjoner og basert på insidenstall (3). Planen er at sepsis assosiert med sentralt venekateter også skal inkluderes.

\section{«Effektivt smittevern starter med at ledelsen erkjenner sine forpliktelser»}

usikkerhet i den form de innsamles i dag, og de følger ikke pasientene etter utskrivning. Slike data er ment brukt til å følge utviklingen på eget sykehus og ikke til vurdering av måloppnåelse. For blant annet postoperative sårinfeksjoner er insidenstall sikrere og mer tilgjengelige. Det er disse infeksjonene som bidrar mest til mortalitet, morbiditet og kostnader.

\section{Effektivt smittevern}

Effektivt smittevern starter med at ledelsen erkjenner sine forpliktelser. Reduksjon av sykehusinfeksjoner burde være høyt prioritert i enhver sykehusledelse, men i praksis mangler ofte beslutningskraft. Satsing på reduksjon av sykehusinfeksjoner krever nemlig svar på flere spørsmål:

- Hvilke infeksjonstyper og overvåkingsperioder skal velges?

- Hva slags data skal benyttes - insidensdata eller prevalensdata?

Forskning tilsier at insidenstall bør velges fremfor prevalenstall ved etablering av mål i smittevern (1). Det er derfor synd at Helse Sør-Øst har valgt prevalenstall, og ikke insidenstall, som datagrunnlag for sitt forbedringsarbeid.

Det er postoperative sårinfeksjoner som bidrar mest til lidelse, død og kostnader. Derfor ble Norsk overvåkingssystem for infeksjoner i sykehustjenesten (NOIS) etablert som landsdekkende system for å følge utvalgte inngrep som aortokoronarkirurgi, keisersnitt, hofteprotesekirurgi og etter hvert også colonkirurgi (2). Insidenstall for postoperative sårinfeksjoner imøtekommer det moralske og juridiske aspekt som påhviler sykehuset $\mathrm{i}$ lang tid etter inn-

\section{Mål for smittevernsarbeid}

Helse Sør-Øst har i flere år satt opp mål for sitt smittevernsarbeid. Målene har imidlertid vært upresise og har derfor ikke kunnet brukes i praksis. Målet for 2011 som i motsetning til tidligere år er gjort målbart, lyder: «Sykehusinfeksjoner er redusert til under $3 \%$ \% (4). Mål må imidlertid defineres og presiseres langt mer omhyggelig hvis de skal fungere.

Man bør kunne forlange at erklærte mål for helsetjenester skal være basert på såkalte SMART-kriterier: spesifikke, målbare, ambisiøse/aksepterte, realistiske og tidfestede (5). Målenes egnethet som strategisk arbeidsgrunnlag er avhengig av at de omfattes av faglig konsensus og eksakt formulering. Hvis medarbeiderne ikke ser målene som forståelige, viktige og verdiskapende, tapes muligheten til forbedring.

\section{Erfaringer fra Vestre Viken}

Helse Sør-Øst bør arbeide ut fra Vestre Vikens angrepsvinkel. Vestre Viken, som omfatter sykehusene i Kongsberg, Ringerike, Drammen og Bærum, dekker en befolkning på drøyt 450000 innbyggere, har ca. 6600 årsverk og 800 somatiske senger.

For å sikre effektivitet i smittevernet ble Smittevernavdelingen organisert i stab under direktør for medisin og helsefag. Målene for smittevern i Vestre Viken oppfyller de nevnte SMART-kriteriene og er i samsvar med lov- og myndighetskrav, de overordnede målene til Helse Sør-Øst og Vestre Vikens egne krav. Måletablering for smittevern i Vestre Viken er resultat av langsiktig arbeid som ble startet ved Bærum sykehus da smittevernoverlegen i 2005 implemen- terte ledelsesstandarden for smittevern, DS 2450 (6), som er bygd på ISO 9001 (7).

Manglende måloppnåelse skal utløse forbedringsarbeid. Ledelsen ved Bærum sykehus sørget for nødvendige ressurser og myndighet til smittevernoverlegen slik at fagkunnskap og slagkraft kunne brukes for å bistå avdelingene med gjennomføring av forbedringsarbeid. Flere vellykkede forbedringsprosjekter er blitt gjennomført i perioden 2005-10. Disse har blant annet fort til at forekomsten av infeksjoner etter keisersnitt og Stafylococcus aureus-infeksjoner på Barselavdelingen er blitt vesentlig redusert. Tilsvarende forbedringsarbeid er gjort for hofteproteseoperasjoner. Arbeidet har vært ledelsesforankret og har skapt mye engasjement. Forbedringene består selv etter flere år. Mange av resultatene er under publisering.

\section{Mette Walberg}

mette.walberg@vestreviken.no

Sykehuset Asker og Bærum Vestre Viken

1309 Rud Oppgitte interessekonflikter: Forfatteren er
smittevernoverlege i Vestre Viken.

\section{Litteratur}

1. Mangram AJ, Horan TC, Pearson ML et al. Guideline for prevention of surgical site infection. Inf Control Hosp Epidemiol 1999; 20: 250-78.

2. FOR-2005-06-17-611. Forskrift om innsamling og behandling av helseopplysninger i Norsk overvåkingssystem for infeksjoner i sykehustjenesten (NOIS-registerforskriften). . www.lovdata.no/ ltavd1/filer/sf-20050617-0611.html (24.2.2011).

3. I trygge hender - nasjonal pasientsikkerhetskampanje. www.kunnskapssenteret.no (24.2.2011).

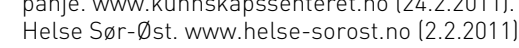

5. NS-EN ISO 9004: 2009 Styring for vedvarende fremgang i en organisasjon. Kvalitetsstyring som metode. Oslo: Norsk Standard, 2009.

6. DS 2450: 2001 Styring af infektionshygiejne - Krav til ledelsessystemet. Charlottenlund: Dansk Standard, 2001

7. NS-EN ISO 9001: 2008 Systemer for kvalitetsstyring - krav. Oslo: Norsk Standard, 2008.

Mottatt 29.10. 2010, første revisjon innsendt 21.12. 2010, godkjent 24.2. 2011. Medisinsk redaktør Petter Gjersvik. 